Research, part of a Special Feature on Reconciling Art and Science for Sustainability

\title{
Creative convergence: exploring biocultural diversity through art
}

\author{
$\underline{\text { Jean L. Polfus }}^{1}$, Deborah Simmons $^{2,3}$, Michael Nevelle $^{2,4}$, Walter Bavha $^{5}$, Frederick Andrew $^{2}, \underline{\text { Leon Andrew }}^{2}$, Bethann G. Merkle $^{6}$, \\ Keren Rice ${ }^{7}$ and Micheline Manseau ${ }^{1,8}$
}

\begin{abstract}
Interdisciplinary approaches are necessary for exploring the complex research questions that stem from interdependence in social-ecological systems. For example, the concept of biocultural diversity, which highlights the interactions between human diversity and the diversity of biological systems, bridges multiple knowledge systems and disciplines and can reveal historical, existing, and emergent patterns of variation that are essential to ecosystem dynamics. Identifying biocultural diversity requires a flexible, creative, and collaborative approach to research. We demonstrate how visual art can be used in combination with scientific and social science methods to examine the biocultural landscape of the Sahtú region of the Northwest Territories, Canada. Specifically, we focus on the intersection of Dene cultural diversity and caribou (Rangifer tarandus) intraspecific variation. We developed original illustrations, diagrams, and other visual aids to increase the effectiveness of communication, improve the organization of research results, and promote intellectual creativity. For example, we used scientific visualization and drawings to explain complex genetic data and clarify research priorities. Visual facilitation during meetings helped establish accurate representations of both cultural and biological diversity by externalizing heterogeneity and avoiding standardization. Group mind mapping enhanced collaborators' ability to visualize connections between Dene concepts, like bets'er̨hchá "respect" and caribou, and to recognize differences between knowledge systems that challenge translations and reduce the effectiveness of research outcomes. Collaborative visual products, like posters that represented different caribou types, allowed Dene partners to more clearly articulate subtleties within caribou intraspecific variation that are manifest through distinct dialects, place-based relationships, and cultural practices. Our results point to the potential for visual art to be used to improve communication, participation, and knowledge production in interdisciplinary and cross-cultural research collaborations and to enhance the sustainable stewardship and protection of biodiversity.
\end{abstract}

Key Words: art; biocultural diversity; biodiversity, bridging knowledge systems; caribou; collaborative research; interdisciplinary; socialecological systems, subarctic; traditional knowledge; visual communication; visual facilitation; visual methods

\section{INTRODUCTION}

Art is increasingly recognized as a crucial component of interdisciplinary research. Visual art and design play a significant role in scientific communication, education, innovation, and public support for research (Curtis et al. 2012). Likewise, new scientific technologies continue to provide artists with contemporary methods of expression (Rieland 2014). Unfortunately, the entrenched and rigid structure of academic departments, designed to facilitate specialized research, has led to an artificial divide between art and the sciences that can limit creative reasoning, cross-fertilization of concepts, and intellectual creativity (Loehle 1990). The fields of art and science have not always been so polarized. Before the advent of photography and digital technologies for reproducing images, drawing was a necessary skill, taught as one of several standard academic subjects (Lerner 2007, Landin 2015). Naturalists, biologists, and specialists in many other fields have long recognized the importance of using visual aids to help communicate and decipher complex concepts (Anker and Nelkin 2004, Curtis et al. 2012). Recently, increased attention is being given to understanding how drawing and other data visualization techniques can be used to portray ideas, organize research results, improve comprehension, explain complex data, and transform public beliefs (e.g., TED talks, infographics, visual abstracts; Ainsworth et al. 2011, Hansen and Machin 2013).
We examine the potential for visual art to aid in interdisciplinary social-ecological research, which explores the dynamic relationships between human cultures, biota, and environments. In the early 1990s, social and natural scientists began to recognize the importance of identifying linkages between human cultural diversity (which may manifest, for example, in language and dialects, specific knowledge of the environment, and unique cultural practices) and the biological diversity of genes, species, and ecosystems (Loh and Harmon 2005, Maffi and Woodley 2010). The variety of cultural and biological diversities, known as biocultural diversity, has the potential to reveal emergent patterns of variation, expose connections between forms of diversity, and provide insight into sustainable management and governance of complex unpredictable social-ecological systems (Kassam 2009, Pretty 2011, Gavin et al. 2015).

Engaging multiple knowledge systems through cross-cultural research with indigenous people is essential to sustainable biocultural research approaches that support equitable ecological decision making and connect knowledge to effective actions (Pretty 2011). Language and practice ground indigenous people's association with biodiversity and encode place-based traditional knowledge of plants and animals (Hunn 2006). Culturally ingrained knowledge of ecosystem processes and dynamics is constantly renewed through frequent interactions with the environment (Ingold 2000). Thus, collaborations with indigenous

\footnotetext{
${ }^{1}$ Natural Resources Institute, University of Manitoba, Winnipeg, Manitoba, Canada, ${ }^{2}$ Rehdzo Got'̨nę Gots'ę Nákedı (Sahtú Renewable Resources Board), Tulit'a, Northwest Territories, Canada, ${ }^{3}$ Aboriginal Studies, University of Toronto, Toronto, Ontario, Canada, ${ }^{4}$ Délınę ?ehdzo Got'ı̨nę (Renewable Resource Council), Délınę, Northwest Territories, Canada, ${ }^{5}$ Délınę Gotine Government, Délınę, Northwest Territories, Canada, ${ }^{6}$ Creative Writing Program, University of Wyoming, Laramie, Wyoming, USA, ${ }^{7}$ Department of Linguistics, University of Toronto, Toronto, Ontario, Canada, ${ }^{8}$ Office of the Chief Ecosystem Scientist, Parks Canada, Gatineau, Québec, Canada
} 
research partners have the potential to enable a more balanced understanding of complex human-ecological connections. However, communicating across language and knowledge systems within interdisciplinary collaborations can be challenging, leading to generalizations that compromise diversity and threaten the integrity of traditional knowledge (Jacobson and Stephens 2009). Effective biocultural research requires a diversity of approaches that can be enhanced by art to advance the interface between disciplines and knowledge systems.

Many important research tools and methodologies have been developed to enable cross-cultural collaborations and to bridge knowledge systems (Berkes 2004, Tengö et al. 2014, Gavin et al. 2015, Rathwell et al. 2015). Among these, art and artistic processes have the potential to enhance collaborative research processes by improving the effectiveness of numerous social-ecological fields, including occupancy mapping (Tobias 2000), complex systems science (Vervoort et al. 2014), social-environmental health and resilience (Castleden et al. 2008, Rathwell and Armitage 2016), and ethnographic communication (Thomsen 2015), among others. Writing and oral communication have limited capacity to convey people's experiences with biodiversity and the complex patterns of the living world (Hunn 2006). Visual art can be effective in building dialogue within interdisciplinary teams and promoting research processes that acknowledge different knowledge bases and cultural contexts. Arts-based research attempts to develop methodological pluralism by combining traditional research methods with the creative and expressive approaches of the arts (Eisner 2006). Emergent methodologies, like participatory art, provide avenues for indigenous people to express important concepts and identify the context and details that ground their traditional knowledge (Castleden et al. 2008, Zurba and Berkes 2014). Similarly, art and art making can bridge knowledge systems and generate new knowledge through collaboration (Rathwell and Armitage 2016). New visualization technologies also enable researchers to tackle social-ecological complexity and to synthesize impacts, trends, patterns, and correlations (Hinke et al. 2004, Frankel and Reid 2008, Hampton et al. 2013, Vervoort et al. 2014).

In the Canadian north, biocultural diversity is often considered to be low because of the constraining effects of harsh ecological conditions that limit the number of species, human cultures, and linguistic groups. However, the regional biocultural diversity of the Arctic and Subarctic is apparent in the distinct practices of family and cultural groups, extensive dialects within languages, and subtle environmental variation that influence all life and can be difficult to quantify (Kassam 2009). Indigenous people's placebased knowledge can help reveal intraspecific diversities that are foundational to functioning systems (Fraser et al. 2006, Kassam 2009). We explore how visual art can be used in combination with scientific methods to examine the biocultural landscape of the Sahtú region of the Northwest Territories (NWT), Canada. Our objective is to demonstrate how visual art can be used to synthesize and inform robust descriptions of indigenous cultural diversity and caribou (Rangifer tarandus) intraspecific variation.

\section{METHODS}

\section{Study area and context}

The Sahtú region occupies $280,238 \mathrm{~km}^{2}$ in central Northwest Territories, Canada. Dene people have lived in the area for thousands of years and maintain strong social-cultural connections to the land and wildlife (Andrews et al. 2012a, $b$, McMillan and Parlee 2013). There are currently five communities in the region; Délınę, Tulít'a, Norman Wells (Tłegóhłı), Fort Good Hope (Rádelı Kọée), and Colville Lake (K'áhbamí Túé).

Although the communities share a common Athapaskan/North Slavey linguistic history, specific family roots and historic cultural relationships generate diversity that is evident in three main dialect groups (Fig. 1): (1) Shúhta (S) "mountain" dialect spoken in Tulít'a, (2) Sahtú (D) "Bearlake" dialect spoken in Délınę, and (3) K'áhsho (K) "Hare" and Dela dialects spoken in Fort Good Hope and Colville Lake. We use the abbreviations S, D, and K following Dene words to distinguish dialects. For a detailed description of the region's biocultural diversity, see Polfus et al. (2016).

Fig. 1. The Sahtú region of the Northwest Territories, Canada, currently includes five communities: Délınę, Tulít'a, Norman Wells, Fort Good Hope, and Colville Lake. Dene people have lived in the region for millennia and share a common Athapaskan/North Slavey linguistic history. However, cultural and linguistic variation between communities reflects historical relationships between people, political agreements, and economic ties. Historic trail use displayed by community helps to reveal, in general, the dynamic spatial patterns of the three main social-linguistic groups, as follows: 1. Tulit'a, including Shúhta Got'lnę, K'áalǫ Got'ı̨nę, and Dəoga Got'ı̨ę (purple), 2. Délınę Got'ınę (red), and 3. Fort Good Hope and Colville Lake, including K'áhsho Got'lnę and Dela Got'lnę (blue; unpublished data, Dene Nation, Dene mapping project 1900-1980).

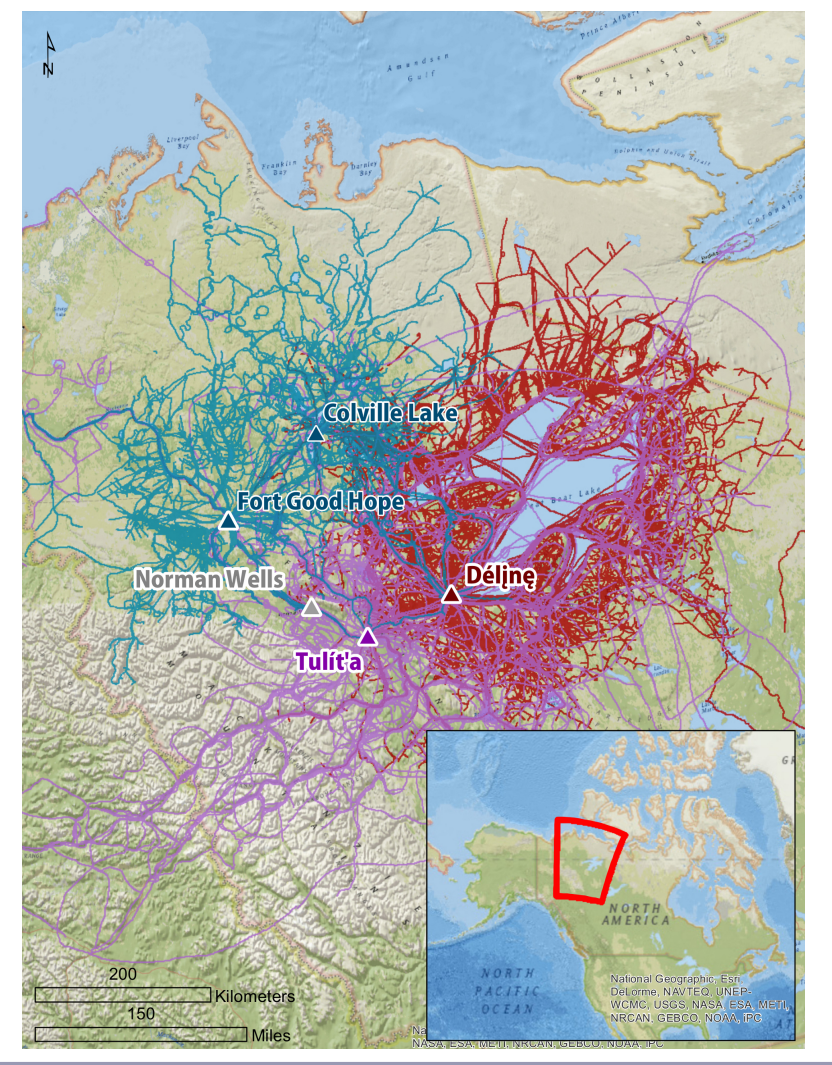


The political and institutional structures of the Sahtu were defined by the Sahtú Dene and Métis Comprehensive Land Claim Agreement (DIAND 1993) that concluded in 1993 and the Mackenzie Valley Resource Management Act (GC 1998) of 1998. Management of renewable resources falls under the mandate of the Rehdzo Got'ı̨ę Gots'ę Nákedı (Sahtú Renewable Resources Board; SRRB) and the five local Rehdzo Got'ınę (Renewable Resources Councils; RRCs). Recent initiatives by the SRRB and RRCs have sought to reframe approaches relating to natural resource research by focusing on innovative ways to include traditional knowledge and Dene laws in research and management (Polfus et al. 2016).

To facilitate these ambitious community objectives, we developed a community-collaborative research project (Tondu et al. 2014) to explore questions about biocultural diversity. An interdisciplinary approach was essential to conducting effective applied research, conservation, and management questions that addressed the interdependent complexity of northern socialecological systems (Folke et al. 2007, Liu et al. 2007, Gavin et al. 2015, Rissman and Gillon 2017). Specifically, we were interested in describing and illuminating connections between caribou variation and the place-based traditional knowledge that is expressed in Dene and Métis people's relationships with caribou. The research drew heavily on participatory research frameworks and methodologies (Ferreira and Gendron 2011), as well as on previous caribou traditional knowledge work carried out by the SRRB (Délınę First Nation 2005, SENES Consultants Ltd. 2009, Sahtú Species At Risk Working Group 2013, 2014). A full description of the project's methods can be found in Polfus et al. (2016).

\section{Focus group and advisory group meetings}

We held a series of meetings in the Sahtú communities of Norman Wells, Fort Good Hope, Tulít'a, and Délınę beginning in December of 2012. Our objectives were to plan the research, develop research questions and priorities, agree on methods, and share both scientific and traditional knowledge about caribou populations in the region. An initial set of focus group meetings were held in each community (including the addition of Colville Lake) during April of 2013. The information shared during the focus group meetings was analyzed and coded (NVivo; QSR International 2010) to develop categories and themes (see Polfus et al. 2016 for further details). To best facilitate the collaborative production of knowledge and coanalysis of traditional knowledge and caribou genetic data, we invited key individuals with an interest in the project to participate in what we initially called an advisory group. Advisory group members quickly became established as research partners and collaborators, who informed the methods, ensured that Dene knowledge was interpreted accurately, and provided additional expertise in traditional knowledge and Dene language.

The first three-day meeting was held in June 2014 and included seven participants who helped select additional elders to participate in a follow-up meeting held in February 2015. All community participants received honoraria. Following the formal meetings, several of the research partners continued to work closely on the project by clarifying details of Dene language translations, presenting research results in schools and during public presentations, and reviewing and coauthoring project manuscripts (Polfus et al. 2016). The interdisciplinary nature of the research team (whose expertise also spanned knowledge and language systems) aided our ability to integrate tools and techniques from multiple disciplines, iteratively refine research questions, develop innovative methodological solutions, find and enhance connections with other ongoing research projects, and respond to community-based wildlife management needs.

\section{Visual facilitation}

We used visual aids to explain population genetic methods, depict the research process and collaborations, and help facilitate the ability of Dene people to share their own understanding about caribou with academic research collaborators. During meetings, we used a mix of Microsoft PowerPoint presentations, whiteboard drawings, flip charts, large sticky notes, word maps, flow charts, diagrams, geographic maps (Google Earth 7.1.5.1557), and mind maps (diagrams that organize relationships between information visually) to represent connections between themes and concepts. The lead author drew original artwork (both digitally and on paper) to represent animals, relationships, and ideas (Figs. 2-5). We also teamed up with a cartoonist who had substantial experience drawing images related to northern resource management and indigenous cultures (Urquhart 2000, 2012). The cartoons inspired our use of bright colors and clear, simple illustrations to depict methods and research processes. For example, we used a simple visual flow chart to show the stages of the research process at every meeting (Fig. 2).

Fig. 2. Diagram depicting the community-collaborative research process that was used during focus group meetings, advisory group meetings, and public presentations. The illustrations of the community-based scat collection and knowledge sharing meetings were developed and drawn by Doug Urquhart for the project and the other two illustrations were developed over the course of the project by the lead author.
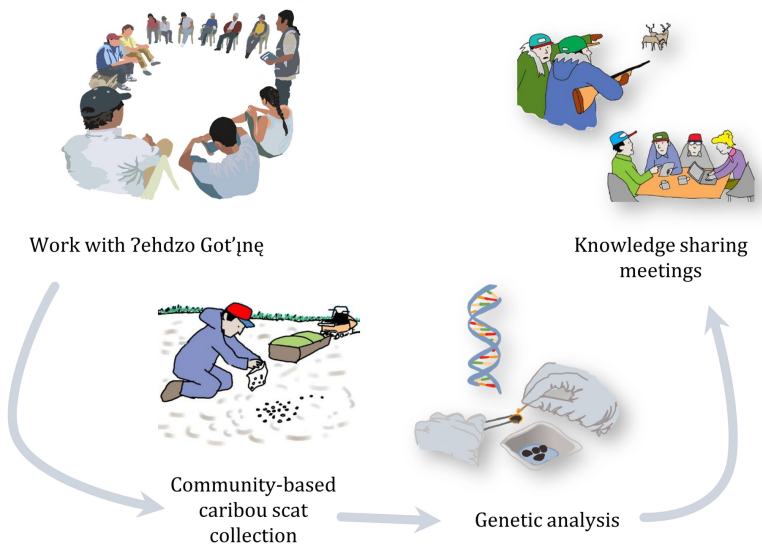

Prior to the first advisory group meeting, we prepared several large flip charts of Dene concepts, caribou types, and Dene words. We also prepared a digital mind map to summarize and organize themes related to caribou genetics, relationships, behavior, language, and traditional knowledge, which had been shared during the first set of focus group meetings. This visual information was used to prepare the meeting agenda and focus 
discussion on key research questions and concepts that required additional validation. To make visual facilitation more adaptive, the mind map was drawn using the open-source graphic editor GIMP v2.8 (www.gimp.org) so the lead author could modify it during the meeting (using a drawing tablet). Modifications were projected, in real time, on a screen at the front of the room. This cumulative and iterative approach allowed us to refine initial categories and concepts to organize research themes with Dene language provided by participants. Before the second advisory group meeting, we coalesced the ideas, Dene words, and concepts from the initial advisory group meeting on large pieces of paper to further refine research questions. We also digitally created drawings of the caribou types and printed them as large posters to be used as participatory tools and to help clarify concepts. In the second advisory group meeting, Dene elders and other collaborators annotated the poster illustrations, clarifying terminology and traditional knowledge of caribou subspecies diversity (Fig. 5).

\section{RESULTS}

The process of using illustrations, diagrams, and other visual aids allowed research collaborators to expand on key research questions and underlying Dene concepts related to biocultural diversity. We discovered early in the research planning process that our explanations and presentations, specifically of population genetic methods, benefitted enormously from complementary drawings that used colors and symbols to illustrate gene flow, population dynamics, and relationships between groups of animals (Fig. 3). Scientific visualizations and drawings helped community members understand and appreciate new, interesting, and sometimes complicated data, for example, like genetic inheritance. However, our initial depictions did not always resonate with audiences that included Sahtú Dene and Métis elders with variable levels of formal western education and English language fluency. We worked closely with community researchers, an expert illustrator (Doug Urquhart), and interpreters to refine and adapt our approach to incorporate culturally appropriate symbols, humor, metaphors, and ecologically correct illustrations (Fig. 3). For example, we avoided stock imagery of caribou, which we found often only includes images of large antlered males, and instead, the lead author drew illustrations to represent male and female animals of different age classes. These biologically representative illustrations more effectively conveyed practical information about gene flow to skilled traditional knowledge holders who had substantial experience with caribou (Fig. 3).

We found that flip charts and images on the walls in the meeting space helped make esoteric and theoretical concepts more tangible. For example, it can be difficult to examine philosophical ideas, like respect, in a cross-cultural and multilingual setting. Challenging translations and naive assumptions can derail dialogue or lead to fundamental misunderstandings. We found that when exploring definitions of Dene words, it can be just as important to ask "What does that look like?" as it is to ask "What does that mean?" In our experience, strong visuals helped ground and center the discussion. At times, discussions involved sustained effort, including repeated explanations and work with sticky notes, flip charts and drawings on the white board, to reach consensus and understanding. The process of developing and agreeing to visual symbols that could be used to represent Dene concepts increased the ability of the research team to focus and refine ideas. We expand on two examples that outline how images helped elucidate both cultural and biological diversity and led to increased clarity of our research questions.

\section{Bets'erihchá "respect"}

Dene concepts, understandings, and values are intricately related to representations of the political, cultural, and economic dimensions of biodiversity (Nazarea 2006). For example, the concept of respect is repeatedly brought up by indigenous people when talking about wildlife and the role of policies related to wildlife management (Délınę First Nation 2005, Legat 2012). However, respect can have very different cultural connotations depending on who is using it and why it is being used. An allencompassing interpretation of respect can also be difficult to identify across cultures because even within cultures definitions and meanings are context specific and culturally diverse. From a western academic perspective, respect includes a sense of reverence or veneration toward a figure deemed to have especially admirable abilities or qualities. However, respect has other interpretations when used across age classes, to promote cultural awareness, during political discourse, in relation to laws, or in the context of religion. Similarly, the interpretation of respect from a Dene perspective is contextual.

Fig. 3. Diagram used in PowerPoint presentations and posters with a visual description of genetic methods. The top two illustrations were drawn by Doug Urquhart and the caribou relationship drawing, photos, and overall design were developed by the lead author.

\section{Methods}

Population genetics allows scientists to understand how different groups of caribou are related to each other in much the same way humans are related to their extended families.

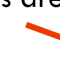

Each caribou has its own individual DNA that is found on the outside mucus layer on caribou scat (poop).

We are able to take DNA from the scat that is found frozen on the snow.
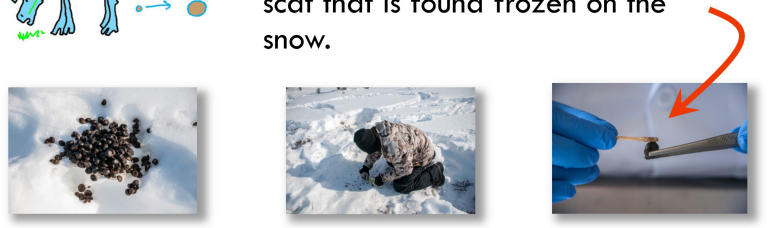

By analyzing the DNA from the caribou scat, we are able to identify how caribou are related to other caribou.
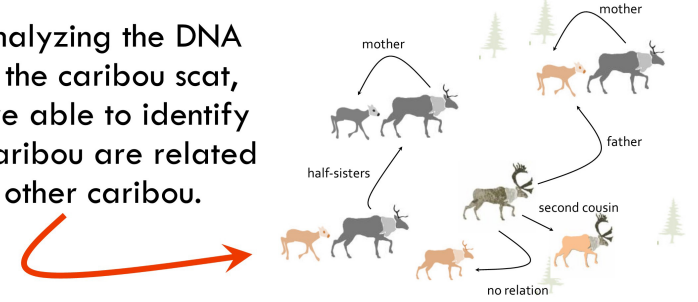
Dene conceptualizations of respect are nonprescriptive and linked to the very individual objective of "living in a good way." Through our discussions, we found it was impossible to separate the concept of respect from the series of practices that characterize Dene relationships with animals. The practical aspects of cultural diversity, such as family-specific behaviors related to how caribou are hunted, are explicitly linked to how individuals practice and conceptualize respect for caribou. Importantly, the distinct environmental conditions (specific habitats and lakes, rivers, mountains, etc.) experienced uniquely by different people across the Sahtú region (Fig. 1) have a strong influence on knowledge about specific caribou habitats and populations, how and why hunts occur, meat preparation techniques, and the language that is used to convey traditional knowledge. Thus, accurate representation of biocultural diversity requires a nuanced understanding of concepts like respect, which portray the variation in knowledge that arises from diverse ecological contexts and avoids standardizing biodiversity (Kassam 2009).

When Dene and Métis people come together from across the Sahtú region there are important protocols for how knowledge is expressed and represented. Knowledge holders defer to individuals from specific subregions (at different scales as appropriate) in recognition that each cultural or family group has their own space and own cultural knowledge.

Walter Bayha explained, respect is

about being Dene, Dene ts'll, and then having that relationship with caribou. That's respect. Asil nezQ bek'ened $[\mathrm{D}]$ means you take care of them [caribou]. But, I think respect would go a lot further than that. See, this is the thing with even the word respect, [in Dene language] it's not even one word.

As Frederick Andrew added:

Respect means bets'erlhchá. When we respect caribou they know it, and in turn, they are there for us. They are always there when we need them, and they provide us with food, clothes, and music.

Another translation of bets'erchchá was expressed as "things that we hold sacred above all" and is related to Dene responsibility to care for animals as well as trusting that animals will provide Dene with the opportunity to survive. Thus, the essence behind the Dene language that is often translated into English as "respect" is deeply integrated with ideas of mutual compassion, trust, and empathy between Dene and caribou.

Dene concepts of respect are directly related to the idea that caribou are rational and self-aware beings that cannot (and should not) be controlled by humans. Dene elders in the Sahtú explain through stories that Dene rekwę́ hịlé (D), "Dene used to be caribou at one time." The stories give agency to animals and explore the alternative perspectives of nonhuman beings. Dene ethics governing acceptable human impacts on caribou include the idea that to treat an animal with respect means to treat them as equal. Hunting is governed not solely by actions of Dene, but just as consciously by the decisions made by the caribou (for further discussion on this topic see Sharp and Sharp 2015). From a Dene perspective, individual caribou allow themselves to be killed to ensure Dene survival. In return, Dene must respect caribou by following locally acceptable practices, many of which promote tecch'ádíı ts'itsıwhíle (D), "killing animals in the most humane and efficient way" and informal regulations, norms and social taboos that govern the treatment of animal remains.

We attempted to elicit distinct knowledge processes and externalize regional cultural diversity during meetings by working with visual representations of the language and dialects (Figs. 4, 5). We found that abstract hierarchical concepts and themes (like key topics) from either or both of the English and Dene perspectives did not necessarily translate easily, either visually or linguistically. We spent significant time during our first advisory group meeting discussing the organization and visual display of the main themes of the group mind map (Fig. 4). The thematic topics that emerged, i.e., (1) Rezah "Dene laws," (2) types of caribou, (3) Así godí hé Dene ts'llı "relationships," and (4) caribou behavior, evolved out of substantial dialogue and are significantly different than what was presented in the original version of the mind map. The concept of bets'erchchá "respect" was coupled with central concepts of rerah, Dene laws. ?erah relate to the ethics and cultural practices that necessitate "living in a good way" and are contextual. A drum was used to symbolize the rerah portion of the mind map because caribou hide drums are critically important to the Dene way of life (Fig. 4).

Frederick Andrew explained:

\section{the drum brings us music, dancing, and hand games and} makes you feel really good inside.

Thus drums are a particularly venerated symbol of respectful cultural practices. Dene approaches to caribou and decision making, and the often critical discussions of governance and policies related to caribou management in the region, also help explain the emphasis on rezah within the context of caribou research. Placing bets'erchchá near zerah in the mind map generated discussion about łegháts'eredı (D), "we give to each other" (symbolized by hands sharing food, Fig. 4) as well as a list of informal rules for the ethical treatment of animals. Leghágots'enete (D), which represents teaching, learning, and sharing the set of ethical practices with others, especially youth, is also tied closely with the concept of respect and was added to the conceptual model during discussions (symbolized by an image of a woman and child, Fig. 4).

Coming to consensus on organizational themes was difficult and we did not have enough time to develop Dene language-driven topics for "behavior" and "types of caribou" or identify adequate Dene imagery and symbols for every concept discussed. In fact, coming up with a Dene concept that encompassed the English word "relationships" (lower right quadrant of Fig. 4) also elicited four additional descriptions that differed dialectically and regionally across the Sahtú. For the purpose of simplicity, we chose así godí hé Dene ts'ill, which translates more literally to "the being of all living things and people" in the collective sense. However, this term requires more discussion to adequately represent the cultural diversity of the concept.

As is the case in most multicultural and interdisciplinary research, the work could not be rushed. During meetings it was necessary to set priorities on the focus of discussions when dealing with complexity. We attempted to balance meeting agendas between 
Fig. 4. The research mind map diagram was developed to explore concepts and connections between Dene themes and research questions related to caribou with advisory group participants in June 2014. Where possible, thematic topics that were used to guide the agenda and focus discussions are represented with Dene concepts and Dene imagery. The topic areas are clockwise from top left: 1. Rerah "Dene laws," 2. Types of caribou, 3. Así godí hé Dene ts'clı "relationships," and 4. Caribou behavior. Images were drawn by the lead author. Shúhta (S) "mountain" dialect spoken in Tulít'a, Sahtú (D) "Bearlake" dialect spoken in Délı̨nę, and K'áhsho (K) "Hare" and Dela dialects spoken in Fort Good Hope and Colville Lake. We use the abbreviations S, D, and K following Dene words to distinguish dialects.

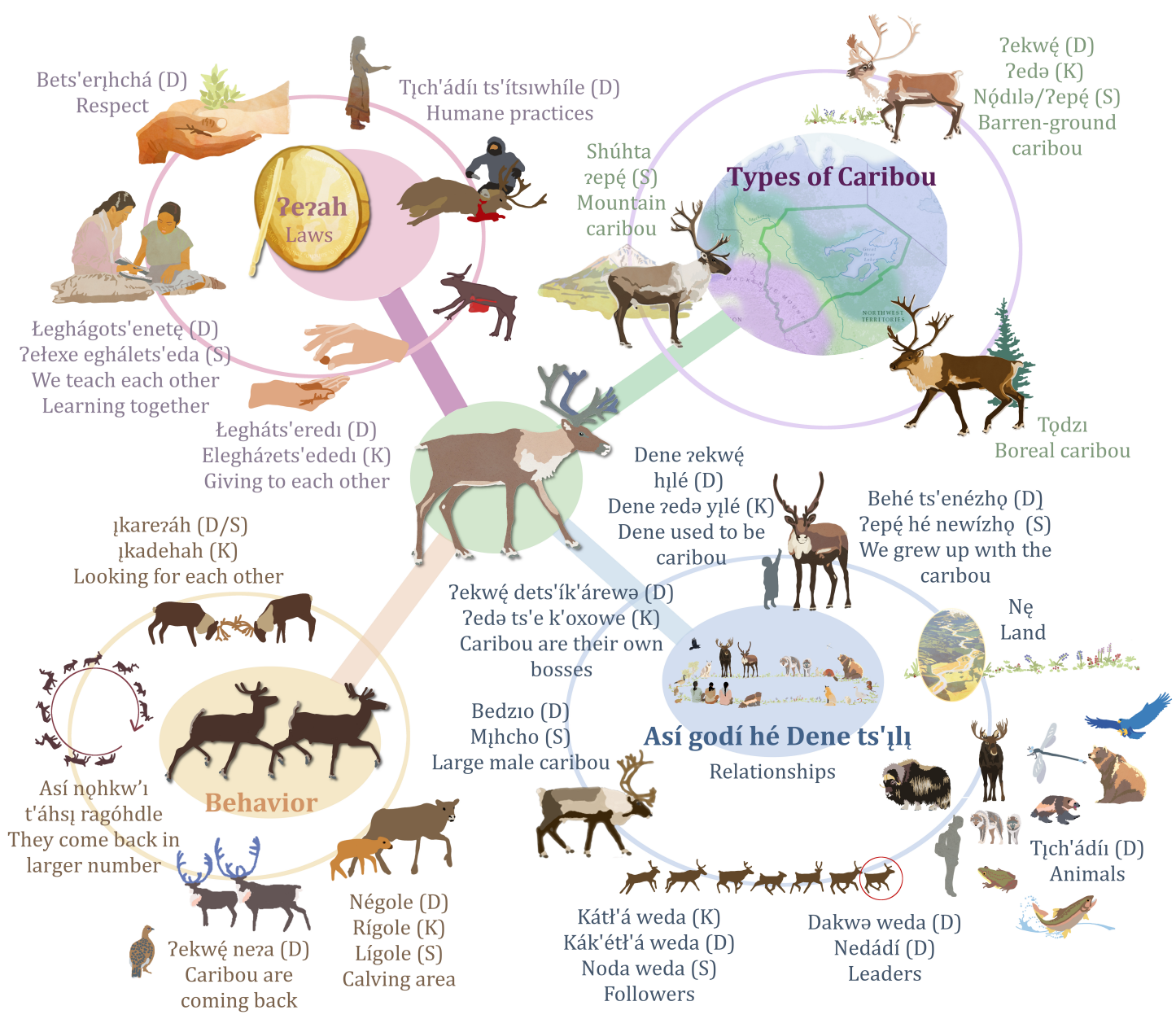

academic research questions and compelling community-driven research priorities that were important to address at the time. Time and relationship building (within this project and through continued traditional knowledge explorations as part of the SRRB's broader research agendas) were critical to the success of our research processes. We anticipate continued work on Dene biocultural concepts and place-based biodiversity knowledge in future research initiatives.

\section{Caribou biodiversity}

Caribou are phenotypically diverse and are adapted to different habitats across their distribution. This variation is displayed in behavioral differences, numerous fur colors and patterns, size discrepancies, and specific life history traits. The inherent variation of caribou has made developing taxonomic categories for the species difficult, and many different iterations of subspecies, ecotypes, and populations have been proposed both internationally and within Canada (Flagstad and Røed 2003, COSEWIC 2011). Thus, collaborating with indigenous people who have extensive historic relationships with caribou has the potential to provide representations of caribou that acknowledge biodiversity and variation within a specific region, using criteria that may not always be identified by western-science-informed species taxonomies. An important component of our research project was to understand the Dene conceptualizations and language used to describe different types of caribou in the Sahtú region and synthesize how these types of caribou relate to population genetic differentiation (Polfus et al. 2016). To achieve 
this objective, we needed to address the biocultural landscape of the region and understand how variation is revealed through distinct place-based relationships and practices that Dene people have developed over millennia with caribou.

Fig. 5. Images from the advisory group meetings depicting various visual facilitation techniques: (a) The lead author adds key ideas to the whiteboard (depictions of hoof shapes) and flip-chart illustrations of the different types of caribou during the first advisory group session in June 2014; (b) Details of the flip-chart illustration for zekwę́/zedə/ıepé (D/K/S) "barrenground caribou" and todz1 "boreal caribou" including notes with Dene language in the three main dialects of the Sahtú region; (c) Details from the draft of the large poster depicting further explanations and additional information added by participants of the second advisory group meeting held in February 2015; and (d) Participants of the second advisory group meeting work together on the large todzı poster.
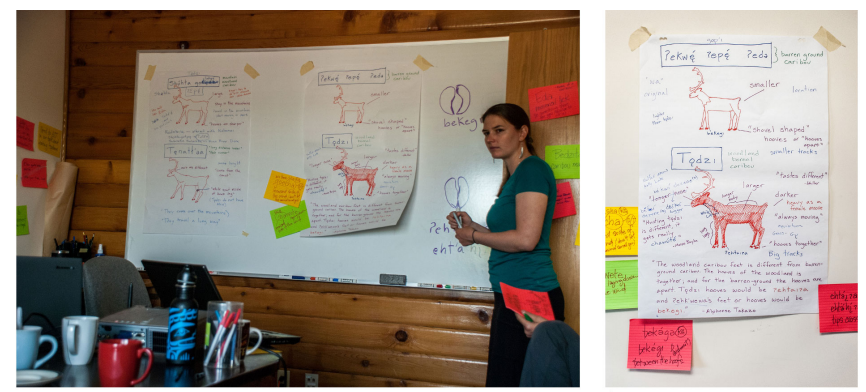

a.

b.
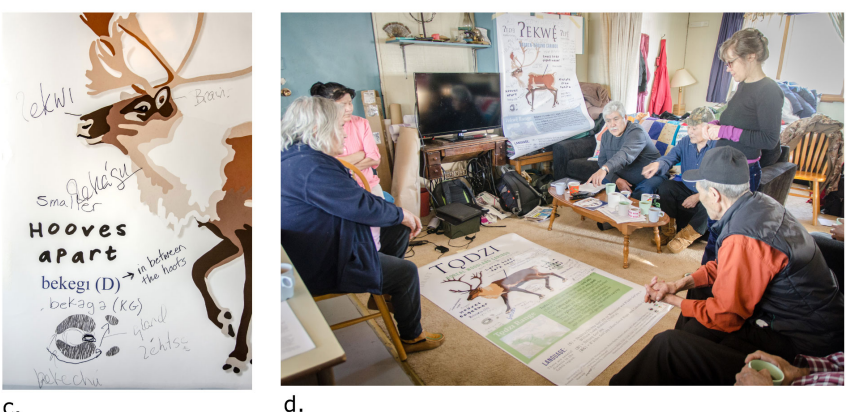

Initially, we found it challenging to clearly articulate Dene traditional knowledge and words specific to different types of caribou in the region. Dene language definitions of caribou were complicated by divergence among the three main dialects of the Sahtú region, the individual variation in caribou appearance (even within types), and each participant's specific life experiences. Thus, we found it was essential to create original illustrations to facilitate the development of robust traditional knowledge descriptions of caribou variation. Because particular types of caribou have also been defined by biologists, taxonomists, and government policies like the Canadian Species at Risk Act, it was also essential to avoid back-translating English concepts and names into Dene language. For example, through visual facilitation during advisory group sessions it became apparent that using the term gokwí (D) "barren-land or tundra" as a modifier to describe barren-ground caribou (gokwí rekwé (D), literally "barren-land caribou", which had been used in some previous research projects) did not accurately reflect how Dene people used their language to convey meaning about caribou. Instead, Dene people have dialect-specific names for barrenground caribou that vary across the region. The words are used in context and convey different meaning depending on who is speaking, what dialect is being used, what questions are being addressed, where on the land the speaker is located, and the dialect or background of the audience. Additional supporting information could be provided if the speaker needed to make it clear that they were referring to a specific type of caribou or just speaking of all caribou in general.

Clear visual depictions of caribou helped participants come to agreement on overlap between caribou words and definitions for the three main types of caribou within the Sahtú region: 1. tǫdz1 (D,S,K) "boreal caribou", 2. rekwęe (D), redə (K), nọdılə (S), repé (S) "barren-ground caribou" and 3. shúhta repé (S) "mountain caribou" (Polfus et al. 2016). Illustrations also provided a template for refining physical and behavioral characteristics recognized by Dene people as being representative of each type of caribou. We initially developed separate drawings on flip charts for each type of caribou that had been discussed in previous meetings (Fig. 5a, b). At the first advisory group meeting, we reviewed differences in caribou size, shape, color, and behavior and added Dene words and concepts to the initial draft of the illustrations. Participants slowly came to a consensus through this visually facilitated discussion. Participants requested that the illustrations be turned into posters and used as teaching tools to help share caribou knowledge with youth. Dene partners realized that communityspecific posters would be required to accurately represent regional dialects. At the second advisory group meeting, participants were invited to draw on the updated poster drafts, adding ideas and changing words or details as necessary (Fig. 5c,d).

Illustrations also helped us explore the question of how hunters could use caribou tracks to determine which type of caribou was present in an area. Initial sketches and discussion had resulted in two different shapes of tracks for zekwę (D) and tǫdzı. However, when working closely with knowledgeable elders (who spoke several dialects) at the second meeting, we found that the word bekágə (K) or bekég1 (D) referred to the space between the hooves (rather than hoof shape) that holds a gland called réhtse (D; Fig. $5 \mathrm{c})$. The insights into the Dene words for hooves and tracks might not have been as clear without using drawings to depict the actual image of a hoof to the entire group. Participants agreed that identifying the type of caribou that left a track could be best established based on location, habitat type, group size, and size of the tracks. The illustrations gave participants the opportunity to more clearly understand research questions and compare specialized language about the different caribou types that is used by expert hunters and elders from different family groups. Similarly, the illustrations facilitated discussion and description of additional caribou features. For example, when presented with a poster of a caribou, elders were quick to add words and descriptions for the neck area, nose, stomach, antler beams, warble flies, caribou foods, scat and many other details that had not been discussed previously but demonstrated detailed knowledge of complex phenotypic differences among caribou types.

A visual approach to biocultural research enabled us to develop clear synergies between Dene traditional knowledge about 
caribou variation and caribou population genetics. Specifically, the three main types of caribou articulated through illustration by Dene people informed and corresponded with caribou genetic subpopulation structure identified through analysis of microsatellites and mitochondrial DNA from caribou fecal pellets (for full explanation see Polfus et al. 2016). Our research vividly illustrates the detailed knowledge that Dene people have about differences among caribou and, in doing so, demonstrates that Dene knowledge is a valid and essential platform for interpreting scientific (in this case genetic) data (Polfus et al. 2016). Understanding the more nuanced components of Dene traditional knowledge and language relating to caribou variation would have been much more difficult without the use of original illustrations and the visual participation of Dene collaborators. After being verified, the caribou posters will be presented to the communities as educational tools to help with transmission of language, traditional knowledge, scientific knowledge, and the promotion of bets'erlhchá "respect."

\section{DISCUSSION}

Our research project demonstrates the potential for visual art to increase communication and exchange of knowledge between interdisciplinary and cross-cultural research teams while at the same time illuminating and addressing biocultural diversity. Connections between Dene cultural diversity and environmental variation have shaped the ecological dynamics of the Sahtú region for millennia. Analysis of the multifaceted links between ecological and cultural diversity can provide insights into unique ecological histories and identify approaches for sustainable use of resources into the future (Maffi and Woodley 2010, Polfus et al. 2016). The first step to identifying and supporting local diversities is through a flexible and creative approach to research. Indigenous people's traditional knowledge describes biological variation that is interrelated with unique cultural identities and dialects. Research that generalizes people's knowledge stands to lose opportunities to understand how regional heterogeneity, in both culture and biodiversity, interacts to produce patterns of biocultural diversity on the landscape (Kassam 2009). Art can illuminate the wide array of processes that cultures have developed to understand their environments. Thus, art offers researchers effective ways to identify, clarify, and convey biocultural concepts that are elicited from local people through different social-ecological methods. Biocultural diversity is not static, and, by acknowledging the dynamic nature of relationships with the natural world, it is possible to build more robust representations of social-ecological systems (Kassam 2009). In our research we used illustrations to identify, understand, and depict distinct Dene conceptualizations of relationships with caribou and the caribou biodiversity that is identified through those relationships. Specifically, we found that visual methods enhanced communication, participation, and accurate representation of regional biocultural diversity.

\section{Communication}

Visual art is a powerful communication tool (Curtis et al. 2012). In many cases, the use of visualizations can reveal ideas that are difficult to comprehend through oral communication alone (Cornwall and Jewkes 1995, Hunn 2006). This is especially true when knowledge is represented within different knowledge systems and languages (Rathwell and Armitage 2016). When faced with increased levels of knowledge complexity during meetings, it can be difficult not to retreat to simplistic explanations, which obscure critical details that are challenging to express orally (Sibbet 2010). Further, images can be used to quickly convey information to facilitate group discussions. For example, when Dene language is interpreted to English on the spot (as is often the case in multilingual meetings), clarity can be lost because of constraints on the interpreter's ability to instantly transform technical statements between languages. Visuals, like drawings of caribou, can aid in this type of interpretative context by increasing the level of detail available to the speakers and the audience. Phrases like "those caribou are darker" can be vague and lack the contextual information required for shared understanding. Instead, multiple illustrations of caribou that depict the contrast between different shades of fur can instantly convey information that is cumbersome to express in words, especially across languages. Furthermore, short verb-based phrases in Dene language (for example descriptions of specific hunting techniques) transmit significant information to native speakers, but lack resolution when translated into English. Drawing depictions of the hunting techniques on the whiteboard illuminated technical Dene phrases that were difficult to translate because they encoded so much meaning (e.g., goecha gots'anele (S), "to hunt from downwind," described in Polfus et al. 2016).

Importantly, images can act as shared reference points that help to externalize private knowledge and enable effective dissemination of ideas (Ainsworth et al. 2011, Rathwell and Armitage 2016). The shared experience of perceiving an image allows for the establishment of a common level of understanding so that dialogue can advance to deeper and more complex topics. We found that the images of caribou and Dene concepts in our meeting space exposed shared knowledge and allowed the research team to advance more quickly to collaborative knowledge generation. For example, it is common in crosscultural meetings for individuals to take turns providing statements of their own expert knowledge. This structure often includes repetitive elements, like generic descriptions of DNA inheritance or generic descriptions of caribou and respect. Providing a visual representation of this type of information allows both the presenter and their audience to demonstrate their understanding of baseline knowledge. Thus, artistic representations can produce a more dynamic form of back and forth communication and lead to deliberate and explicit analyses of specific research questions like caribou relationships or the diverse conceptualizations of respect. Visualizations allow interdisciplinary teams to develop group memory, organize background knowledge, and make alternative viewpoints accessible; all of which increase the exchange of information and the clarity of emergent ideas (Sibbet 2010, Ainsworth et al. 2011).

Art can also be an important tool for communicating research results to the general public (Curtis et al. 2012). There is growing recognition for the responsibility of scientists to reach beyond their disciplines and share their results more broadly (Baron 2010, Smith et al. 2013). Unfortunately, science communication is challenged by the pressures of modern academia and funding agencies that reward publication in high-impact academic journals (Smith et al. 2013). Collaborative visual research processes can also provide products and tools for public outreach. During our meetings, community partners appreciated the chance 
to work on research outcomes, like the caribou posters, that had direct and identifiable use in the Sahtú schools. At the same time, academically situated members of our research team benefitted from the images for use in conference presentations and public outreach beyond the Sahtú region (Merkle 2016). Thus, a focus on visual art during the research process not only contributed to positive synergies among research priorities; art also helped us share research findings with those most impacted by potential research outcomes. Comanagement authorities have used similar artistic products to help promote conservation and wildlife management initiatives in the region. For example, the book, Remember the Promise, used illustrations by our lead author and Dene language to describe how species are protected through the Northwest Territories Species at Risk Act (GNWT 2009) and how species at risk policies sync with important Dene concepts and practices (Sahtú Species At Risk Working Group 2014). In this way, visual art can express traditional knowledge in new contexts that present opportunities to connect with youth and the public (Islam et al. 2016, Rathwell and Armitage 2016). Additionally, the book reminds non-Dene policy makers to integrate indigenous culture when developing legislation and management strategies.

\section{Participation}

Visual facilitation during meetings promotes active listening and participation because individuals' contributions are acknowledged and recorded graphically (Sibbet 2010). In a media landscape that is saturated with photographs, original illustrations provide a refreshing and intriguing context. Featuring original artwork during meetings immediately improves group engagement and promotes active listening (Valenza and Adkins 2009, Sibbet 2010). Engagement is essential to interdisciplinary collaborations, especially those that require input from all group members to produce output that is representative of cultural diversity. Art is also a medium that is open for critique from diverse and crosscultural audiences, unlike academic manuscripts. For example, the posters featuring caribou illustrations allowed academic research partners to present preliminary results for review by Dene knowledge holders and elders in an accessible format. Asking participants to write and draw directly on the posters also elicited active participation in a shared research product (Fig. 5). By turning communication into a visual practice, rather than verbal, we provided a unique avenue for multilingual participants to demonstrate their knowledge.

Participatory art has been widely used to build collaborations between researchers and indigenous communities and empower participants to define their own visual representation that expresses connections between culture, environment, political systems, and community well-being (Castleden et al. 2008, Zurba and Berkes 2014, Zurba and Friesen 2014, Rathwell and Armitage 2016). Further, participatory art can encourage collaborative processes that address important dimensions of social-ecological systems by bringing together people from different backgrounds to share in an inclusive dialogue around a piece of art (Zurba and Friesen 2014, Rathwell and Armitage 2016). In fact, the creative processes and interactions that are required in participatory art projects can act as powerful tools for reconciliation and selfdetermination (Zurba and Friesen 2014). Although our project's initial goal was not to produce collaborative artwork, we were able to use participatory visualization approaches to effectively evoke specialized traditional knowledge (e.g., Dene words and names for different caribou anatomy that were added to the posters), build deeper understandings of research topics and themes, and develop visuals useful for communicating socialecological knowledge and biodiversity to local and broader audiences.

Participatory approaches also illuminate diversity within groups by confirming the legitimacy of multiple voices and points of view (Rathwell and Armitage 2016). For example, working with the mind map (Fig. 4) during our advisory group meeting allowed community research collaborators to expand on important cultural concepts and use Dene language to describe research themes. The visual representation of ideas within the mind map enabled nuanced reflection on the diverse experiences of different people and allowed cultural diversities to resonate more clearly among collaborators. Mind maps and other symbolic diagrams have been shown to enhance a group's ability to see connections between topics and find alternate ways to represent ideas, especially when concepts are bound closely with cultural ideologies and personal mental models (Sibbet 2010, Davies 2011). Highlighting multidimensional connections within mind maps during meetings can also allow interdisciplinary research teams to work together to recognize where important differences between knowledge systems exist (Winowiecki et al. 2011). Notably, these differences often occupy conceptual spaces where translations between languages can break down. Identifying disparities in how knowledge is organized and presented among cultures can been seen as an opportunity to: (1) open dialogue, (2) examine how different knowledge systems visualize the world, and (3) explore how approaches to problems may vary. In many cases these differences offer a chance to learn together and generate new insights through collaboration.

The mind map developed for our research project was used to both organize traditional knowledge that had been shared in previous meetings and highlight priorities for further verification during the first advisory group meeting. Thus, although the mind map was adapted and modified by the group during the meeting, the initial work on its organization was done in preparation for the meeting. Additional research will be able to address this limitation by initiating the creation of original mind maps during meetings. This type of participatory method can help academic researchers assume the role of facilitator and catalyst, rather than director (Cornwall and Jewkes 1995). Inclusive group facilitation techniques, like mind mapping, have the potential to provide better creative autonomy over projects and develop an even more representative picture of shared ideas (Winowiecki et al. 2011, Zurba and Friesen 2014, Rathwell and Armitage 2016).

\section{Representation}

Our research benefitted enormously from the use of customized illustrations, which we developed to increase clarity and communication, during all phases of the research process. Importantly, these illustrations were often modified to represent updated information or address newly identified areas of confusion in an adaptive and applied way. Specific illustrations of caribou, Dene people, behaviors, and concepts, which also reflected Sahtú Dene and Métis cultural iconography, provided an important platform for discussions of cultural diversity and caribou variation. The unique illustrations, which we developed 
specifically for the project, also allowed academic research partners to establish credibility with skilled Dene knowledge holders. For example, depicting accurate caribou morphology demonstrated that traditional knowledge and teachings that had been shared previously were heard and recognized. Further, by carefully choosing culturally relevant imagery, like drums or caribou, we ensured participants were able to see their own identities represented during the research process, which helped build trust and relationships between research partners. By building our own visual aids and avoiding confusing and nonspecific images, we were able to successfully engage with community partners on a deeper level.

Illustrations were essential because they allowed the advisory group to focus on the symbolic characteristics of each type of caribou. Although photographs are powerful conduits of information, in many circumstances, the extra information represented in a photograph can impede people's ability to isolate important characteristics (Monoyios 2011). For example, when presented with a photograph of a caribou, hunters will often ask for specific information about the location, time of year, and other clarifying details that would be important in the context of hunting. Skilled hunters also recognize that a photograph of a caribou represents just one individual, and individual caribou are known to show variation in physical features. On the other hand, a drawing can convey select information about spatial patterns and relationships quickly and clearly (Keller 2011, Monoyios 2011). A drawing is more easily seen as a generalized representation and allows important contrasts between various kinds of animals to be identified. Illustrations can also represent multiple ideas in a single image (e.g., overlays, diagrams to communicate processes, etc.) while at the same time eliminating distracting or superfluous details (Jennifer 2015).

One important consideration of our research was that almost all illustrations used in the project were generated by one researcher, the lead author, with the addition of a few early contributions by Doug Urquhart. Because symbols are culture specific, the way that ideas are expressed visually will differ between people, languages, and knowledge systems. Our reliance on one artist's interpretation of the research process and results limits the ability of our images to represent alternative worldviews. Working with only one artist ensures a stylistically coherent body of images, which can also be valuable. Nonetheless, future research collaborations would benefit from the perspectives of artists with diverse backgrounds who could develop Dene imagery for specific topics, like bets'erchchá. Future research should prioritize indigenous art as a way to express knowledge and improve collaborative and interdisciplinary social-ecological projects (Rathwell and Armitage 2016).

\section{Conclusion}

Strong visuals were essential to the successful communication and implementation of our community-collaborative research through all stages of the research process. Our approach builds on similar research that suggests that visual methods can improve communication, especially among knowledge systems and languages, and that artistic processes should be considered a fundamental component of interdisciplinary social-ecological research methodologies and practices (Rathwell and Armitage 2016). In collaborative research, it is essential to draw upon the expertise of a diversity of people that span knowledge systems, language expertise, artistic abilities, and familiarity with specialized tools and techniques, i.e., from ecology, social sciences, and linguistics, to population genetics, visual design, and art (Gavin et al. 2015, Knapp et al. 2015, Pittman et al. 2016). Artistic ability can be fostered as a fundamental cross-cultural skill, and, much like humor, is a valuable contribution to collaborative teams that need to connect knowledge systems and develop sustainable solutions. We propose that investing in collaborations with artists is an effective way to enhance and improve biocultural or socialecological research outcomes.

Though art is a culturally specific act with local representations, visualizations have the potential to incorporate universal elements of communication and provide a platform for comprehensive analysis that can encompass multiple research elements simultaneously. Interdisciplinary biocultural research must bridge not only distinct disciplinary barriers but also differing knowledge systems and languages. We demonstrate the potential for visual art to aid biocultural research processes and foster connections and understandings among academic researchers and indigenous community members. We found that refined visuals, such as illustrations, expanded the communication capacity of our diverse collaborative team. Art promotes creativity and enhances techniques that make it possible to codevelop research questions and collaboratively analyze research results.

Art can also be used to emphasize self-governance, indigenous stewardship, and local authority over biodiversity management while at the same time asserting cultural distinctiveness (Pretty 2011). For example, a local Dene artist was recently asked to attend a Délınę Caribou Working group meeting focused on developing a community-driven caribou management plan. The artist listened to the ideas that were communicated and produced images that reflected the community stories shared during the meeting. The final artwork was used in the resulting plan and provided community ownership to the project in ways that were visually compelling and immediately apparent to everyone involved (Délınę Rekwę́ Working Group 2016). Supporting cultural practices, dialects, and place-based knowledge presents opportunities for people to define their identity and assert the uniqueness of their perspective (Kofinas et al. 2000). By supporting diversity and encouraging creativity, through visual approaches, it is possible to facilitate a unique convergence of ideas across knowledge systems that enhances the sustainable stewardship of biodiversity (Tengö et al. 2014, Gavin et al. 2015).

Responses to this article can be read online at: http://www.ecologyandsociety.org/issues/responses. $\mathrm{php} / 8711$

\section{Acknowledgments:}

This research project was a collaboration among various individuals and institutions in the Sahtu region of the Northwest Territories, including the Rehdzo Got'ınę Gots'ę Nákedl (Sahtú Renewable Resources Board), the Rehdzo Got'tne (Renewable Resources Councils) and the NWT Department of Environment and Natural 
Resources (ENR). The participants of the two advisory group meetings were essential collaborators on this project and shared extensive knowledge for the purpose of the research. We are indebted to them: Michael Neyelle, Walter Bayha, Jimmy Dillon, Gordon Yakeleya, Frederick Andrew, Leon Andrew, Maurice Mendo, Michel Lafferty, Judy Lafferty, Richard Kochon, Hyacinthe Kochon, Gabe Kochon, Lucy Jackson, and Camilla Rabisca. We extend special thanks to Tisha and Benny Doctor for providing accommodations during our meeting held at Deochah "Bennett Field" and to Corrine Andrew for cooking for the group. The SRRB board and staff provided financial, logistical, and administrative support for this project. Particular thanks are owed to Catarina Owen, Lori Ann Lennie, Kristen Kodakin, and Joe Hanlon. We thank Phil Spencer of ENR for help printing the caribou posters and Kristi Benson for preparing the Dene trails map. Doug Urquhart passed away in December of 2015. Over the years he developed a unique style of illustrations and cartoons that he used to depict life in the north and assist with cross-cultural natural resource management issues. His humorous and potent portrayals of people and wildlife have positively contributed to many important projects, including ours. We thank Doug for his generosity and passion for art and conservation. He will be greatly missed. The principles and protocols governing the research were covered by a multiyear research license from the Aurora Research Institute (15217, 15443, and 15597), wildlife research licenses from ENR (WL500104, WL500307), and a University of Manitoba Ethics Protocol (J2012:202). Funding for this project was provided by SRRB, ENR, Cumulative Impact Monitoring Program, Environmental Studies Research Fund, Parks Canada, University of Manitoba, and an NSERC Strategic Grant held by MM. JLP thanks Claire Polfus and Morgan Moffitt for reviewing early versions of the manuscript and the Wilburforce Foundation for support through the Wilburforce Fellowship in Conservation Science.

\section{LITERATURE CITED}

Ainsworth, S., V. Prain, and R. Tytler. 2011. Drawing to learn in science. Science 333:1096-1097. http://dx.doi.org/10.1126/ science. 1204153

Andrews, T. D., G. MacKay, L. Andrew, W. Stephenson, A. Barker, C. Alix, and the Shúhtagot'ine Elders of Tulita. 2012a. Alpine ice patches and Shúhtagot'ine land use in the Mackenzie and Selwyn Mountains, Northwest Territories, Canada. Arctic 65:22-42. http://dx.doi.org/10.14430/arctic4183

Andrews, T. D., G. MacKay, and L. Andrew. $2012 b$. Archaeological investigations of alpine ice patches in the Selwyn Mountains, Northwest Territories, Canada. Arctic 65:1-21. http:// dx.doi.org/10.14430/arctic4182

Anker, S., and D. Nelkin. 2004. The molecular gaze: art in the genetic age. Cold Spring Harbor Laboratory, Cold Spring Harbor, New York, USA.

Baron, N. 2010. Escape from the ivory tower: a guide to making your science matter. Island, Washington, D.C., USA.

Berkes, F. 2004. Rethinking community-based conservation. Conservation Biology 18:621-630. http://dx.doi.org/10.1111/ j.1523-1739.2004.00077.x

Castleden, H., T. Garvin, and Huu-ay-aht First Nation. 2008. Modifying Photovoice for community-based participatory indigenous research. Social Science and Medicine 66:1393-1405. http://dx.doi.org/10.1016/j.socscimed.2007.11.030

Committee on the Status of Endangered Wildlife in Canada (COSEWIC). 2011. Designatable units for caribou (Rangifer tarandus) in Canada. Committee on the Status of Endangered Wildlife in Canada, Ottawa, Ontario, Canada.

Cornwall, A., and R. Jewkes. 1995. What is participatory research? Social Science and Medicine 41:1667-1676. http://dx. doi.org/10.1016/0277-9536(95)00127-S

Curtis, D. J., N. Reid, and G. Ballard. 2012. Communicating ecology through art: what scientists think. Ecology and Society 17(2):3. http://dx.doi.org/10.5751/es-04670-170203

Davies, M. 2011. Concept mapping, mind mapping and argument mapping: what are the differences and do they matter? Higher Education 62:279-301. http://dx.doi.org/10.1007/s10734-010-9387-6

Délıné First Nation. 2005. Dene ways of respecting the land and animals. Final report to the Sahtú Renewable Resources Board. Sahtú Renewable Resources Board, Délınę, Northwest Territories, Canada.

Délınę Rekwę́ Working Group. 2016. Belarewile Gots'é Rekwę (Caribou for all time): a Délıné Got'lne plan of action. Délınę Rekwę́ Working Group, Délınę́, Northwest Territories, Canada.

Department of Indian Affairs and Northern Development (DIAND). 1993. Sahtú Dene and Métis comprehensive land claim agreement. Government of Canada, Department of Indian Affairs and Northern Development, Ottawa, Ontario, Canada. [online] URL: https://www.aadnc-aandc.gc.ca/eng/1100100031147/1100100031164

Eisner, E. 2006. Does arts-based research have a future? Inaugural lecture for the first European conference on arts-based research Belfast, Northern Ireland, June 2005. Studies in Art Education 48:9-18.

Ferreira, M. P., and F. Gendron. 2011. Community-based participatory research with traditional and indigenous communities of the Americas: historical context and future directions. International Journal of Critical Pedagogy 3:153-168. [online] URL: http://libjournal.uncg.edu/ijcp/article/view/254

Flagstad, Ø., and K. H. Røed. 2003. Refugial origins of reindeer (Rangifer tarandus L.) inferred from mitochondrial DNA sequences. Evolution 57:658-670. http://dx.doi.org/10.1111/ j.0014-3820.2003.tb01557.x

Folke, C., J. Colding, P. Olsson, and T. Hahn. 2007. Interdependent social-ecological systems. Pages 536-552 in J. Pretty, A. Ball, T. Benton, J. Guivant, D. Lee, D. Orr, M. Pfeffer, and H. Ward, editors. Sage handbook on environment and society. Sage, London, UK.

Frankel, F., and R. Reid. 2008. Big data: distilling meaning from data. Nature 455:30. http://dx.doi.org/10.1038/455030a

Fraser, D. J., T. Coon, M. R. Prince, R. Dion, and L. Bernatchez. 2006. Integrating traditional and evolutionary knowledge in biodiversity conservation: a population level case study. Ecology and Society 11(2):4. [online] URL: http://www.ecologyandsociety. org/vol11/iss2/art4/ http://dx.doi.org/10.5751/es-01754-110204 
Gavin, M. C., J. McCarter, A. Mead, F. Berkes, J. R. Stepp, D. Peterson, and R. Tang. 2015. Defining biocultural approaches to conservation. Trends in Ecology and Evolution 30:140-145. http:// dx.doi.org/10.1016/j.tree.2014.12.005

Government of Canada (GC). 1998. Mackenzie Valley resource management act. Government of Canada, Ottawa, Ontario, Canada. [online] URL: http://laws-lois.justice.gc.ca/eng/acts/ $\underline{\mathrm{M}-0.21}$

Government of the Northwest Territories (GNWT). 2009. Species at risk (NWT) act. Government of the Northwest Territories, Species at Risk Secretariat, Yellowknife, Northwest Territories, Canada. [online] URL: http://www.nwtspeciesatrisk. ca/content/documents

Hampton, S. E., C. A. Strasser, J. J. Tewksbury, W. K. Gram, A. E. Budden, A. L. Batcheller, C. S. Duke, and J. H. Porter. 2013. Big data and the future of ecology. Frontiers in Ecology and the Environment 11:156-162. http://dx.doi.org/10.1890/120103

Hansen, A., and D. Machin. 2013. Researching visual environmental communication. Environmental Communication 7:151-168. http://dx.doi.org/10.1080/17524032.2013.785441

Hinke, J. T., I. C. Kaplan, K. Aydin, G. M. Watters, R. J. Olson, and J. F. Kitchell. 2004. Visualizing the food-web effects of fishing for tunas in the Pacific Ocean. Ecology and Society 9(1):10. [online] URL: http://www.ecologyandsociety.org/vol9/iss1/art10/ http://dx.doi.org/10.5751/es-00626-090110

Hunn, E. 2006. Meeting of minds: how do we share our appreciation of traditional environmental knowledge? Journal of the Royal Anthropological Institute 12:S143-S160. http://dx.doi. org/10.1111/j.1467-9655.2006.00277.x

Ingold, T. 2000. The perception of the environment: essays on livelihood, dwelling and skill. Routledge, London, UK. http://dx. doi.org/10.4324/9780203466025

Islam, D., M. Zurba, A. Rogalski, and F. Berkes. 2016. Engaging Indigenous youth to revitalize Cree culture through participatory education. Diaspora, Indigenous, and Minority Education :1-15. http://dx.doi.org/10.1080/15595692.2016.1216833

Jacobson, C., and A. Stephens. 2009. Cross-cultural approaches to environmental research and management: a response to the dualisms inherent in western science? Journal of the Royal Society of New Zealand 39:159-162.

Jennifer, N. 2015. Why science illustration still needs a human touch. Creators Project, Vice, New York, New York, USA. [online] URL: http://thecreatorsproject.vice.com/blog/why-science-illustrationstill-needs-a-human-touch

Kassam, K.-A. S. 2009. Biocultural diversity and indigenous ways of knowing: human ecology in the Arctic. University of Calgary Press, Calgary, Alberta, Canada. [online] URL: http://press. ucalgary.ca/books/9781552382530

Keller, J. 2011. Why sketch? Pages 161-186 in M. R. Canfield, editor. Field notes on science and nature. Harvard University Press, Cambrige, Massachusetts, USA.

Knapp, B., R. Bardenet, M. O. Bernabeu, R. Bordas, M. Bruna, B. Calderhead, J. Cooper, A. G. Fletcher, D. Groen, B. Kuijper, J. Lewis, G. McInerny, T. Minssen, J. Osborne, V. Paulitschke, J.
Pitt-Francis, J. Todoric, C. A. Yates, D. Gavaghan, and C. M. Deane. 2015. Ten simple rules for a successful cross-disciplinary collaboration. PLoS Computational Biology 11:e1004214. http:// dx.doi.org/10.1371/journal.pcbi.1004214

Kofinas, G., G. Osherenko, D. Klein, and B. Forbes. 2000. Research planning in the face of change: the human role in reindeer/caribou systems. Polar Research 19:3-21. http://dx.doi. org/10.3402/polar.v19i1.6525

Landin, J. 2015. Rediscovering the forgotten benefits of drawing. Scientific American 4 September. [online] URL: http://blogs. scientificamerican.com/symbiartic/rediscovering-the-forgotten-benefitsof-drawing/

Legat, A. 2012. Walking the land, feeding the fire: knowledge and stewardship among the Tticho Dene. University of Arizona Press, Tucson, Arizona, USA.

Lerner, N. 2007. Drawing to learn science: legacies of Agassiz. Journal of Technical Writing and Communication 37:379-394. http://dx.doi.org/10.2190/W478-M151-4425-GP03

Liu, J., T. Dietz, S. R. Carpenter, M. Alberti, C. Folke, E. Moran, A. N. Pell, P. Deadman, T. Kratz, J. Lubchenco, E. Ostrom, Z. Ouyang, W. Provencher, C. L. Redman, S. H. Schneider, and W. W. Taylor. 2007. Complexity of coupled human and natural systems. Science 317:1513-1516. $\underline{\text { http://dx.doi.org/10.1126/ }}$ science. 1144004

Loehle, C. 1990. A guide to increased creativity in research: inspiration or perspiration? BioScience 40:123-129. http://dx.doi. org/10.2307/1311345

Loh, J., and D. Harmon. 2005. A global index of biocultural diversity. Ecological Indicators 5:231-241. http://dx.doi. org/10.1016/j.ecolind.2005.02.005

Maffi, L., and E. Woodley. 2010. Biocultural diversity conservation: a global sourcebook. Earthscan, New York, New York, USA.

McMillan, R., and B. Parlee. 2013. Dene hunting organization in Fort Good Hope, Northwest Territories: "ways we help each other and share what we can." Arctic 66:435-447. http://dx.doi. org/10.14430/arctic4330

Merkle, B. G. 2016. Drawn to caribou. American Scientist 104:16-19. http://dx.doi.org/10.1511/2016.118.16

Monoyios, K. 2011. 5 reasons your camera won't steal my job. Scientific American 12 July. [online] URL: http://blogs. scientificamerican.com/symbiartic/httpblogsscientificamericancomsymbiartic201107125-reasons-your-camera-wone28099t-steal$\underline{\text { my-job/ }}$

Nazarea, V. D. 2006. Local knowledge and memory in biodiversity conservation. Annual Review of Anthropology 35:317-335. http://dx.doi.org/10.1146/annurev.anthro.35.081705.123252

Pittman, J., H. Tiessen, and E. Montaña. 2016. The evolution of interdisciplinarity over 20 years of global change research by the IAI. Current Opinion in Environmental Sustainability 19:87-93. http://dx.doi.org/10.1016/j.cosust.2015.12.004

Polfus, J. L., M. Manseau, D. Simmons, M. Neyelle, W. Bayha, F. Andrew, L. Andrew, C. F. C. Klütsch, K. Rice, and P. Wilson. 2016. Leghágots'enetę (learning together): the importance of 
indigenous perspectives in the identification of biological variation. Ecology and Society 21(2):18. http://dx.doi. org/10.5751/ES-08284-210218

Pretty, J. 2011. Interdisciplinary progress in approaches to address social-ecological and ecocultural systems. Environmental Conservation 38:127-139. http://dx.doi.org/10.1017/S0376892910000937

QSR International. 2010. NVivo. Version 10. QSR International, Doncaster, Australia.

Rathwell, K. J., and D. Armitage. 2016. Art and artistic processes bridge knowledge systems about social-ecological change: an empirical examination with Inuit artists from Nunavut, Canada. Ecology and Society 21(2):21. http://dx.doi.org/10.5751/ es-08369-210221

Rathwell, K., D. Armitage, and F. Berkes. 2015. Bridging knowledge systems to enhance governance of environmental commons: a typology of settings. International Journal of the Commons 9:851-880. http://dx.doi.org/10.18352/ijc.584

Rieland, R. 2014. 7 ways technology is changing how art is made. Smithsonian Magazine 27 August. [online] URL: http://www. smithsonianmag.com/arts-culture/7-ways-technology-is-changinghow-art-is-made-180952472/?no-ist

Rissman, A. R., and S. Gillon. 2017. Where are ecology and biodiversity in social-ecological systems research? A review of research methods and applied recommendations. Conservation Letters 10:86-93. http://dx.doi.org/10.1111/conl.12250

Sahtú Species At Risk Working Group. 2013. Report of the Sahtú species at risk terminology workshop. Rehdzo Got'ınę Gots'ę Nákedı (Sahtú Renewable Resources Board) and the Species at Risk Secretariat, GNWT Environment and Natural Resources, Délınę, Northwest Territories, Canada. [online] URL: http:// www.nwtspeciesatrisk.ca/sites/default/files/final report of sar sahtu workshop 13-11-01.pdf

Sahtú Species At Risk Working Group. 2014. Kədə Nit'Q Benats'adl (Remember the promise). Compiled by B. Harnum and D. Simmons. Sahtú Renewable Resources Board, Tulit'a, Northwest Territories, Canada.

SENES Consultants Ltd. 2009. Rekwę Hé Naldé - living with caribou: traditional knowledge program 2005-2009 management and policy implications - preliminary review. Compiled by D. Simmons. Sahtú Renewable Resources Board, Tulit'a, Northwest Territories, Canada.

Sharp, H. S., and K. Sharp. 2015. Hunting caribou: subsistence hunting along the northern edge of the boreal forest. University of Nebraska Press, Lincoln, Nebraska, USA.

Sibbet, D. 2010. Visual meetings: how graphics, sticky notes and idea mapping can transform group productivity. John Wiley and Sons, Hoboken, New Jersey, USA. http://dx.doi. org/10.1002/9781119200086

Smith, B., N. Baron, C. English, H. Galindo, E. Goldman, K. McLeod, M. Miner, and E. Neeley. 2013. COMPASS: navigating the rules of scientific engagement. Plos Biology 11:1-5. http://dx. doi.org/10.1371/journal.pbio.1001552
Tengö, M., E. S. Brondizio, T. Elmqvist, P. Malmer, and M. Spierenburg. 2014. Connecting diverse knowledge systems for enhanced ecosystem governance: the multiple evidence base approach. AMBIO 43:579-591. http://dx.doi.org/10.1007/ s13280-014-0501-3

Thomsen, D. C. 2015. Seeing is questioning: prompting sustainability discourses through an evocative visual agenda. Ecology and Society 20(4):9. http://dx.doi.org/10.5751/es-07925-200409

Tobias, T. N. 2000. Chief Kerry's moose: a guidebook to land use and occupancy mapping, research design and data collection. Union of BC Indian Chiefs and Ecotrust Canada, Vancouver, British Columbia, Canada. [online] URL: https://www.fws.gov/ nativeamerican/pdf/tek-chief-kerry.pdf

Tondu, J. M. E., A. M. Balasubramaniam, L. Chavarie, N. Gantner, J. A. Knopp, J. F. Provencher, P. B. Y. Wong, and D. Simmons. 2014. Working with northern communities to build collaborative research partnerships: perspectives from early career researchers. Arctic 67:419-429. [online] URL: http://arctic. journalhosting.ucalgary.ca/arctic/index.php/arctic/article/view/4416

Urquhart, D. 2000. Eyes of the husky: Skookum's penetrating insights into the hearts and minds of northerners. Harbour, Madeira Park, British Columbia, Canada.

Urquhart, D. 2012. The null hypothesis: co-management doesn't work. Rangifer 20:103-112. http://dx.doi.org/10.7557/2.32.2.2258

Valenza, C., and J. Adkins. 2009. Understanding visual thinking: the history and future of graphic facilitation. Interactions 16:38-43. http://dx.doi.org/10.1145/1551986.1551994

Vervoort, J. M., D. H. Keuskamp, K. Kok, R. van Lammeren, T. Stolk, T. (A.) Veldkamp, J. Rekveld, R. Schelfhout, B. Teklenburg, A. Cavalheiro Borges, S. Jánoškóva, W. Wits, N. Assmann, E. Abdi Dezfouli, K. Cunningham, B. Nordeman, and H. Rowlands. 2014. A sense of change: media designers and artists communicating about complexity in social-ecological systems. Ecology and Society 19(3):10. http://dx.doi.org/10.5751/ es-06613-190310

Winowiecki, L., S. Smukler, K. Shirley, R. Remans, G. Peltier, E. Lothes, E. King, L. Comita, S. Baptista, and L. Alkema. 2011. Tools for enhancing interdisciplinary communication. Sustainability: Science, Practice and Policy 7:74-80. [online] URL: https://sspp. proquest.com/tools-for-enhancing-interdisciplinary-communicationf165ae225b7b\#.8jinzqprz

Zurba, M., and F. Berkes. 2014. Caring for country through participatory art: creating a boundary object for communicating Indigenous knowledge and values. Local Environment 19:821-836. http://dx.doi.org/10.1080/13549839.2013.792051

Zurba, M., and H. A. Friesen. 2014. Finding common ground through creativity: exploring indigenous, settler and Métis values and connection to the land. International Journal of Conflict and Reconciliation 2:1-34. [online] URL: https://www.researchgate. net/publication/270049710 Finding Common Ground through_Creativity_Exploring_Indigenous_settler_and_Metis_values and connection to the land 